\title{
The Impact of Capital Structure on the Performance of Industrial Commodity and Services Firms Listed on Vietnamese Stock Exchange
}

\author{
Vuong Quoc Duy
}

\author{
Associate Professor Doctor in Economics, College of Economics, Can Tho University, Vietnam
}

\begin{abstract}
This paper investigates the impact of capital structure on the performance of commodity and service firms listed on the Vietnamese Stock Exchange. Data used in the paper were collected from the 142 firms listed on Ho Chi Minh and Ha Noi Stock Exchange during time 2009-2015. By using the descriptive statistics and linear regression model, the findings shows that there is negative relationship between capital structure (e.i. STD. LTD and DA) and peformance of the firms (i.e. ROE) for the commodity and services firms listed on two given Stock Exchange Market of Vietnam. Following are possible implications for the study.
\end{abstract}

Key words - Capital structure, Performance, Commodity and Service firms, Vietnam.

\section{INTRODUCTION}

The capital structure is referred as the combination of debt and equity used to finance a firm's investment oppurtunities. Such combination can be a mix of debt and equity. Equity may be generated from the internally equity and new issue equity. However, what the best combination is still a debatable question for many researchers and practioners mind?

Pratheepkanth (2011) suggested that the relationship between captial structure and financial performance are one that established significant attention in the finance literature. In addition, the capital structure is a complex set of decision making choice for any firm (Myers, 1984) which is a significant tool where the firms have to maintain the control of its profit and loss through the possible combination of debt and equity of capital structure (Derayat, 2012). Firm's performance is another important issue which are concerned by the shareholders and creditors of the firms, particularly in the purpose of financial decision making leads to increase the value of shareholders of the firms (Bradley et al., 1984).

It is widely accepted that it is difficult for the firms to define the proportion of the equity and the debt in the optimal capital structure to maximize the profit, minimize the risk and the weight of cost of capital. It is significant that the optimal combination of equity and debt capital play a crucial role in obtaining goals of investors of the firm, and it has become meaningful for the firms to measure the effect of capital structure on performance which affects their capital structure decision making to achieve the firm objectives. As a result, capital structure and firms performance studies and tests are attracting the researchers and scholars on the world in general and in Vietnam in particular. Therefore, this study also aims at investigating the impact of capital structure on the performance of 142 industrial commodity and services of firms listed on the Vienamese Stock Exchange from 2009 to 2015.

This paper is constructed into 5 parts. First part is the introduction. Second part illustrates the literature reviews on the capital structure studies. Methodology is presented in the third part. Fourth part shows the findings. Conclusion and recommendations regarding to the capital structure and other factors affecting on the performance of firms will be on the last part.

\section{LITERATURE REVIEW}

\subsection{Capital structure theories}

\subsubsection{Trade off theory}

This theory stated that a company chooses its capital structure by balancing the costs and benefits of equity and debt. Traditionally, Kraus and Litzenbeger (1973) suggested that there should be a balance between the dead weighted cost of bancruptcy and the tax saving benefits of the debt. Agency cost can also be considered as a part of it. The theory also illustrates the fact that there is an advantage of using debt as source of financing in the form of tax benefit and there is a cost of financing capital structure with debt, there is the cost of financial distress in the form of bankcruptcy cost of debt and non-bankcruptcy costs. As debt increases the marginal cost of debt increases while the marginal benefits of debt declines, therefore the firm, which is optimizing its overall value, 
should concern this trade-off when chosing between debt and equity as a source of finance.

\subsubsection{Market timings theory}

The market timings theory suggests that the firms issue new stock as the stock price is overvalued and buy back their shares in times of undervaluation. Therefore, the stock prices can influence the firm's capital structure. It is widely accepted that the capital structure dynamics can be driven by two versions of equity market timings. Firstly, it considers the economics agents to be rational. Normally, the firms issue equity directly over positive information this reduces the asymmetry conflict between the management and stockholders. As decrease in information asymmetry coincides with an increase in stock price the firms generate their own oppurtunities. Secondly, it assumes economic agents to be irrational (Baker and Wurgler, 2002). Base on this theory, a timevarying mispricing of stock of the company arises due to the irrational behavior. The presence of an irrationally low cost results managers to issue equity and on the other hand the presence of irrationally high costs leads to repurchase of equity.

\subsubsection{Pecking order theory}

This theory was proposed by Donaldson in 1961 and was modified by Meyers and Nicolas in 1984. This theory suggested that a company should prioritize its source of financing first from internal financing and then moving on the equity, considering the cost of financing raising money from equity shold be company's last option. Therefore, internal funds should be used first and when it is not sufficient the debt should be issued. After issuing the debt if a company needs more fund and if its not a sensible to issue more debt the equity should be issued. Managers have known very well about the company prospects, its risk and value than its investors. This leads to the asymmetric information problem, affecting the choice between internal and external source of financing. This validates the existence of pecking order theory while choosing the source of financing. As a company issues debt over equity it implies that board is condifent that the investment project is profitable and this will impact favorably on its share price. Nethertheless, issuing equity presents that the board is not confident enough for the project and it can affect negatively on the current stock price of the company. As a result, the investors think that managers want to take the advantage of the overvaluation of their shares, hence placing a lower value for the new shares. However, this theory has some exceptions, for instance, I does not apply to high technology industries where the board prefers to issue equity because of the high cost of debt.

\subsection{Literature Reviews}

There are a number of previous studies of capital structure and profitability. Among others, Derayat (2012) investigated the relationship between capital structure and profitability of 135 companies listed in Tehran Stock Exchange for a period from 2006 to 2010. The findings stated that there is a positively significant relationship between capital structure and profitability of the companies. Moreover, Nimalathasan and Brabete (2010) studied the impact of capital structure in profitability in randomly selected thirteen lested Manufacturing companies in CSE of Sri Lanka for period of 05 years from 2003 to 2007. He found that capital structure measured by debt to equity is positively and strongly associated with profitability in terms of gross profit margin, operating profit margin and not profit margin. In constract to above study, Prahalathan and Ranjani (2011) examined the impact of capital structure on firm's performance in Sri Lanka. Data were collected from 65 list Sri Lanka companies listed on CSE for the period from 2003 to 2007. The findings showed that capital structure found to have significant negative influence gross profit margin. Similarly, Pratheepkanth (2011) suggested that the relationship between capital structure and financial performance is negative. Contracdicting to Derayat (2012), Olufunso et al (2010) revealed that the usage of debt in small and meidum enterprises of manufacturing industry in the Buffalo City Municipality of South Africa has a signifcantly negative effect on their profitability when he investigated the impact of usage of debt on the profitability of 45 small and medium enterprises (SMEs) in the given location and the data were collected over the period from 2005 to 2006. Gill, et al., (2011) sought to extend Abor's (2005) findings regarding the effect of capital structure on profitability by examining the effect of capital structure on profitability of the American service and manufacturing firms. The empirical results of the study show a positive relationship between short-term debt to total assets and profitability and between total debt to total assets and profitability in the service industry.

Furthermore, Makunyi (2011) did a study on the relationship between working capital investment policy and profitability of manufacturing firms in Kenya and concluded that no relationship exists between the working capital investment policy and profitability. Another study of Mose (2011) on the relationship between capital structure and financial performance of microfinance institutions in Kenya found that outreach and portfolio size had a positive effect on financial performance of MFIs in Kenya. In addition, Kweri (2011) investigated the relationship between working capital management and profitability of manufacturing firms listed at the Nairobi 
Stock Exchange and concluded that working capital management affects profitability of the company and if the firm can effectively manage its working capital, it can lead to increasing profitability. In the same year 2011, Caffaso in her study on the relationship between working capital management financing policy and profitability among manufacturing firms in Kenya concluded that there was negative relationship between ROA and financing working capital policy. Peviously, Zulqar \& Mustafa (2007) examine the relation between capital structure and performance of firm. Result shows that there is a relationship between capital structure and firm performance. Furthermore, Tapanjeh (2006) examined the relationship between firm's structure and profitability by using data from 48 Jordanianlisted industrial companies at Amman Stock Exchange for a period of one decade, from 1995-2004. His findings showed that total debt to asset ratio proxy for capital structure has a positive significant ralation with return on equity whereas firm size illustrated significant negative relation with ROE thus stated that capital structure is a useful issue affecting on firm performance.

FakherBuferna, KenbataBangassa and Lynn Hodgkinson (2005) investigated the determinants of capital structure of the firms Evidence from Lybia and provided empirical evidence for theories of capital structure. Independent variables which can explain for the capital structure were financial leverage report and explanatory variables were firm size, firm growth opportunities, and debt ratio of firm assets and profitability of the firm. The sample of this research was based on 5 years by treating the data from 1995 to 1999 for 55 companies. Selection of sample companies included in the framework of public and private companies. The sample included 32 public companies and 22 private companies. To test the relationship between debt level explanatory variables to those used econometric methods to the amount of small squares. Results showed that private companies have tended to rate the highest average growth and more assets than public companies. Otherwises, the findings indiated that private companies have higher levels of short-term debt than public companies, which means that private companies had the highest rate debt than the average public company.

\section{METHODOLOGY}

This paper investigates the impact of capital structure on the performance of industrial commodity and services of firms listed on the Vienamese Stock Exchange. Data were collected by 142 firms listed on the Ho Chi Minh Stock Exchange and Ha Noi Stock Exchange of Vietnam from 2009-2015, classified as small and medium firms according to law in force that defines the activity of firms in the real sector of economy. The significant data, which are used in this paper are the financial report provided by the respective firms. The methodology used in the paper is built on the basic of the methodology that the small amount of squares, using data to cross. This method enables that through multivariable regression analysis, to analyze the effects of different variables that influence business decision, on the basic that capital and firm performance. So main purpose of the methodology that small amount of squares to be applied through regression analysis that multivariable change is forecast to average dependent variables (performance), as a result of unit change in explanatory variables.

To obtain given objective, following function was considered:

$\mathrm{ROE}=\mathrm{f}(\mathrm{STD}, \mathrm{LTD}, \mathrm{D} / \mathrm{A}, \mathrm{DAA} \& \mathrm{PLACE})$

Where:

ROE is return rate; it corresponds to the net profit divided by the equity.

STD corresponds to the Short term debt to Total Asset.

LTD is the Long term debt to Total asset.

DAA corresponds to Total debt to Total Asset Squared.

PLACE is the place of firm's listed which is 1 if the firms were listed on the Ho Chi Minh stock Exchange, and 0 otherwise.

ROE indicates the rate of return proportional to the equity, STD, LTD, DAA show the capital structure of the firms, representing the Short term debt, long term debt to Total assets, Total debt to total Asset squared and the place where firms were listed, respectively.

\section{FINDINGS AND DISCUSSIONS}

For our quantitative analysis, the paper used the correlation between variables and regression analysis. Correlation between variables will help us to measure the association between explanatory variables and the association with dependent variable. Correlation is calculated for all explanatory variables. Regression analysis is used to accurately measure the indidual effect of explanatory variables in the relation between variable and their dependent one.

\subsection{Descriptive statistics}

The ROA, ROE, STD, LTD and D/A characteristics are presented in the table 1 . 
Table.1. Descriptive statistics of the variables

\begin{tabular}{llllll}
\hline Variable & N & Min & Max & Mean & Standard deviation \\
\hline ROA & 558 & $-25,78$ & 58,76 & 7,6873 & 8,91208 \\
ROE & 558 & $-64,03$ & 78,35 & 13,8145 & 15,97544 \\
STD & 558 & 0,00 & 0,98 & 0,5509 & 0,35133 \\
LTD & 558 & 0,00 & 1,00 & 0,2875 & 0,29206 \\
DA & 558 & 0,00 & 1,00 & 0,4335 & 0,28577 \\
\hline
\end{tabular}

(Source: The outcome of descriptive statistics by Stata)

The operational efficiency representing by ROA of the commodity and services firms listed on the Vietnamese Stock Exchange are on average 7.69 percent, minimum at minus 25.78 percent and maximum at 58.76 percent respectively with the standard deviation of 8.91 percent. In addition, the ROE figure of given firms are on average of 13.81 percent, minimum at -64.03 percent, maximum at 78.35 percent with the standard deviation of 15.89 percent, respectively.

The average STD of the mentioned firm is 55.09 percent with the standard deviation of 35.13 percent. The highest and lowest STD of the firms are $98.00 \%$ and $0.00 \%$ respectively. Different from the STD, the LTD of surveyed firms is average on the 28.75 percent of its total assets with the standard deviation of 29.21 percent.

In addition, the total debt to total asset (D/A) of the commodity and service firms listed on the Vietnamese Stock Exchange is on 43.35 percent with the deviation of 28.58 percent. This means the given firms have the D/A level with highly votility.

The descriptive statistics on the location of commodity and service firms listed on the Vietnamese Stock Exchange are showed in the table 2.

Table.2: The sample by the Stock Exchange

\begin{tabular}{llll}
\hline Listed Stock Exchange & Observation & Percentage & Cummulative Percentage \\
\hline Ha Noi Stock Exchange & 341 & 61,1 & 61,1 \\
Ho Chi Minh Stock & 217 & 38,9 & 100,0 \\
Exchange & & 100,0 & \\
Total & 558 & & \\
\hline
\end{tabular}

(Source: The outcome of descriptive statistics by Stata)

Table 2 illustrates that among observation, the firms listed on the Ha Noi Stock Exchange are higher with 61.1 percent than those listed on the Ho Chi Minh Stock Exchange with 38.9 percent. This can be explained that most of commodity and service firms size are small and medium size regarding to its total assets. In addition, the larger firms are often listing on Ho Chi Minh Stock Exchange while the smaller ones posted its shares on the Ha Noi Stock Exchange.

The independent variables' characteristics are showed in the table 4.3.

Table.3: Independent variables characteristics by the Stock Exchange

\begin{tabular}{llllll}
\hline Items & ROA & ROE & STD & LTD & DA \\
\hline Ha Noi Stock Exchange & & & & & \\
Minimum & $-25,78$ & $-64,03$ & 0,00 & 0,00 & 0,00 \\
Maximum & 58,76 & 76,39 & 1,0 & 1,0 & 0,98 \\
Mean & 6,51 & 12,22 & 0,552 & 0,2856 & 0,4549 \\
S.D & 7,72 & 14,94 & 0,352 & 0,2939 & 0,2787 \\
Ho Chi Minh Stock Exchange & & & & \\
Minimum & $-18,74$ & $-30,68$ & 0,00 & 0,00 & 0,00 \\
Maximum & 54,96 & 78,35 & 1,00 & 0,99 & 0,97 \\
Mean & 9,54 & 16,32 & 0,548 & 0,2906 & 0,3999 \\
S.D & 10,27 & 17,22 & 0,35 & 0,2897 & 0,294
\end{tabular}

(Source: The outcome of descriptive statistics by Stata) 
Table 3 summarizes independent variables regarding to the Stock Exchange place of the commodity and service firms. The performance of the average ROA for whole Vietnamese Stock Exchange is about 7.69 percent. The highest ROA of the market is 58.76 percent while the lowest one is 25.78 percent. The ROA of Companies listed on the Ho Chi Minh Stock Exchange is on average of 9.54 percent that is higher than that of companies listed on the Ha Noi Stock Exchange 6.51 percent.

The table also provides the value of ROE for among given Stock Exchanges. For the Vietnam as a whole, it is average 13.81 percent in which the highest ROE one is about 78.35 percent and the lowest one is minus 64.03 percent. Particularly, The ROE of the companies listed on the Ho Chi Minh Stock Exchange is average 16.32 percent that is higher than that of companies listed on the Ha Noi Stock Exchange of 12.22 percent.

The performance of STD for whole Vietnamese Stock Exchange is about 55.09 percent. The highest STD of the market is 58.76 percent while the lowest one is $25.78 \%$. The STD of Companies listed on the Ho Chi Minh Stock Exchange is on average of 54.8 percent that is lower than that of companies listed on the Ha Noi Stock Exchange 55.2 percent.

The proportion of long-term debt/equity (LTD) company is average 28.75 percent. Companies listed on the Ho Chi Minh Stock Exchange have long-term debt ratio/average equity 29.06 percent higher than that of 28.56 percent of the companies listed on the Ha Noi Stock Exchange.
Total debt/total assets (D/A) of the listed companies is average 43.35 percent in which the D/A of companies listed on the Ho Chi Minh Stock Exchange has a ratio of debt/total assets 39.99 percent that is lower than the D/A of companies listed on the Ha Noi Stock Exchange of 45.49 percent.

4.2. The impact of capital structure on the performance of commodity and service firms listed on the Vietnamese Stock Exchange

A linear regression model to determine the effect of capital structure to the performance of the performance of commodity and service firms listed on the Vietnamese Stock Exchange using the ROE, including the long term debt/total assets (LTD), total debt/total assets (D/A) and the plate points listing of companies (HOSE and HNX) defined intended and interpreted as in table 4

The findings showed that five variables taken into the model are statistically meaningful through the level of significance of 1 percent. The location (Place) has the same dimensional relationship with ROE. The variables of short-term Debt/total assets (STD), long-term Debt/total assets (LTD), total debt/total assets (DA) has a negative coefficient effecting on the ROE and the DAA variable is not significant influence on the ROE of the firms. The R-squared coefficient ( $\mathrm{R}$ Square) is 0.714 meaning that the performance of firms can be explained by the variables included in the model 71.4 percent.

Table.4: The result of linear regression model on ROE

\begin{tabular}{|c|c|c|c|}
\hline Variables & Coefficients & t-Value & VIF \\
\hline Constant & $25,649^{* * *}$ & 27,054 & \\
\hline Place & $8,493^{* * *}$ & 9,583 & 1,336 \\
\hline STD & $-5,686^{* * *}$ & $-4,662$ & 1,334 \\
\hline LTD & $-7,946^{* * *}$ & $-4,244$ & 2,186 \\
\hline DA & $-20,357^{* * *}$ & $-3,167$ & 3,538 \\
\hline DAA & $-19,208$ & $-1,617$ & 2,195 \\
\hline $\mathrm{R}^{2}$ & & & 0,714 \\
\hline F test & & & 278,432 \\
\hline Probability of $F>0$ & & & 0,000 \\
\hline
\end{tabular}

(Source: The outcome of descriptive statistics by Stata)

Notes: *** significant at 1\%; ** Significant at 5\%

The linear model can be written as follows:

$\mathrm{Y}=25,649+8,493 \mathrm{Place}-5,686 \mathrm{STD}-7,946 \mathrm{LTD}-$ 20,357DA

The model determines the capital structure to influence the performance of the commodity and service firms listed on Vietnames Stock Exchange as follows:

Firstly, the Place is defined as the Stock Exchange where the shares of firms have been listed on is significantly effect on the performance of the firms. The finding also indicates that the effective use of capital of firms listed on the Ha Noi and Ho Chi Minh Stock Exchange differ each other. Other factors are constants, the performance of the firms listed on the Ho Chi Minh Stock Exchange is higher than that of firms listed on the Ha Noi Stock Exchange.

Secondly, variable STD (short-term Debt/total assets) has the value of zero meaning that the STD is statistically affecting on the performance of the firms. The result indicates that other variables are constant, the short-term 
Debt to Total assets increase, the performance of firm (ROE) can be decreased. The short-term debt presented negative sign and level of significance of 1 percent, showing to be an important variable in the model. The explanation for such fact can resite in the low relative participation of that type of debt, and can also suggest that STD is a common practice among the most profitable companies, considered the instability of the Vietnamese economy, which arises the need of short run funds to provide the necessary working capital - which are the type of resources supposedly offered with relative abundance and easiness by financial institutions.

Thirdly, the long-term debt divided by total equity (LTD) has a larger explanation power in the model, and its negative sign indicates an inverse relationship. Thus, the larger the debt, the lower is the ROE (performance of the firms.Specifically, when long-term Debt/equity increases, the effective use of capital reduce on condition that the other factors constant. These results are in conformity with the conclusions of Ferati and Ejupi (2012), Shubita and Alsawalhah (2012), Gill et al., (2011), Abor (2005), Booth et al., (2001), Fama and French (1998), Graham (2000).

Fourthly, the variable total debt/total assets (DA) can affect the performance of of the firms at $1 \%$ significance level. The research results showed that the total debt/total assets are inversely correlated, or when the total debt/total assets increased the effective use of capital will decrease if other factors do not change. The findings indicates the a negative relationship with Firm's performance. This is due to the fact that debts are relatively more expensive than equity, and therefore employing high proportions of them could lead to low the performance (ROE) of firm. This shows equity to be the main financing option chosen by the listed non financial firms in Viename. The results support earlier findings by Fama and French (1998), Graham (2000), and Booth et al. (2001).

\section{CONCLUSIONS AND APPLICATIONS}

\subsection{Conclusions}

This paper investigates the impact of capital structure on the performance of commodity and service firms listed on the Vietnamese Stock Exchange. Data used in the paper were collected from the 142 firms listed on Ho Chi Minh and Ha Noi Stock Exchange during time 2009-2015. By using the descriptive statistics and linear regression model, the findings shows that there is negative relationship between capital structure (e.i. STD. LTD and DA) and peformance of the firms (i.e. ROE) for the commodity and services firms listed on two given Stock Exchange Market of Vietnam. Following are possible implications for the study.

\subsection{Applications}

The improvement in the performance of the firms is significant issues for the long term survivability of the firms, thus the relationship between capital structure and performance can not be ignored. Particularly, the interest payment on debt is tax deductable, addition of debt in capital structure may lead to the improvement of firm performance. It is widely accepted that a mix of capital structure should be adopted in order to increase the performance of the firms. Moreover, an increase in the level of debt also result the risk of financial distress of the firms. Thus, the firms should put more consideration on internal sources of financing in order to increase their performance. The role play of board managers is significant one to make prudent financing decisions so as to remain profitable and competitive.

The findings also impled that total debt is negatively impact on the performance of the commodity and service firms listed on the Vietnamese Stock Exchange. Therefore, in the case of higher debt, performance will tend to decline. This can be explained that this may due to the high interest bearing securities engaged in the total debt. Moreover, an increase in the level of debt also increases the riskiness of the firms. Thus, firm's management should consider more on internal sources of financing in order to increase their performance.

\section{REFERENCES}

[1] A, R., zulqar, B., \& mustafa , M. (2007). Capital structure and Profitability: case of islamabad stock exchange. international review of business research papers, 3(5), 347-361.

[2] Abor, J. (2005). The Effect of Capital Structure on Profitability: an empirical analysis of listed firms in Ghana. The Journal of Risk Finance, 6(5): 438-445.

[3] Baker, M., and J. Wurgler, 2002, "Market timing and capital structure", Journal of

[4] Booth, L., Aivazian, V., Demirguc-Kunt A. \& V. Maksmivoc, (2001). Capital Structures in Developing Countries, Journal of Finance, 56, (1):87-130.

[5] Bradley, M., Jarrell, G.A., and Kim, E.H. (1984). On the existance of an optimal capital structure: Theory and evidence. The Journal of Finance, 39(3), 857880.

[6] Caffaso, U.A. (2011). Relationship between working capital management financing policy and profitability: A survey of manufacturing firms in Kenya, MBA project University of Nairobi.

[7] Derayat, M. (2012). The investigation of experimental relationship between capital structure and profitability in accepted companies of Tehran 
Stock Exchange (TSE). Journal of Basic and Applied Scientific Research, 2(7), 6517-6522.

[8] Donaldson, G. (1961). Corporate debt capacity: A study of corporate debt policy and the determination of corporate debt capacity. Boston: Division of Research, Harvard School of Business Administration.

[9] FakherBuferna, KenbataBangassa\& Lynn Hodgkinson (2005), "Determinant of Capital Structure Evidence from Libya", No. 2005/08.

[10] FakherBuferna, KenbataBangassa\& Lynn Hodgkinson (2005), "Determinant of Capital Structure Evidence from Libya", No. 2005/08.

[11]Fama, E. F., French, K. R.,1998. Value versus growth: The international evidence. Journal of Finance 53, 1975-1999

[12] Ferati, R., \& Ejupi, E. (2012). Capital Structure and Profitability: The Macedonian case.European Scientific Journal, 8(7), 51-58.

[13] Finance 57.

[14] Gill, A., Nahum B., \& Neil M. (2011). The effect of capital structure on profitability: Evidence from the United States . International Journal of Management, 28(4)1: 3-15.

[15] Gill, A., Nahum B., \& Neil M. (2011). The effect of capital structure on profitability: Evidence from the United States . International Journal of Management, 28(4)1: 3-15.

[16] Graham, J. R., 2000, "How Big are the Tax Benefits of Debt?," Journal of Finance, 55, 1901--1941

[17] Kweri, S.M. (2011). The relationship between working capital management and profitability of manufacturing firms listed at the Nairobi Stock Exchange, MBA project University of Nairobi.

[18] Makunyi, S. K. (2011). The relationship between working capital investment policy and profitability of manufacturing firms in Kenya, MBA project University of Nairobi.

[19]Mose, O. K. (2011). The relationship between capital structure and financial performance of microfinance institutions in Kenya, MBA project University of Nairobi.

[20] Myers S. and Majluf N. (1984). "Corporate financing and investment decisions when firms have information that investors do not have". Journal of Financial Economics, Vol. 13, pp. 187-221.

[21] Myers, S.C (1984). The capital structure puzzle. The Journal of Finance, 39(2), 574-592.

[22] Nimalathasan, B., and Brabete, V. (2010). Capital structure and Its impact on profitability: a study of listed manufacturing companies in Sri Lanka. RevistaTineril or Economist (The Young Economists Journal), 1(15, 7-16.
[23] Olufunso, F.O., Herbst, G., and Lombard, M.r. (2010). An investigation into the impact of the usage of debt on the profitability of small and medium enterprises in the Buffolo city municipally, South Africa. African Journal of Business Management, 4(4), 373-381.

[24] Prahalathan and Ranjani (2011). The impact of capital structure choice on firm performance: Empirical investigation of listed companies in Colombo Stock Exchange, Sri Lanka. International Journal of Research in Commerce and Management, 2(4), 12-16.

[25] Pratheepkanth, P. (2011). Captial structure and financial performance: Evidence from selected bunisness companies in Colombo Stock Exchange Sri Lanka. International Referred Research Journal, 2(2), $171-183$.

[26] Shubita, M. F., \& Alsawalhah, J. M. (2012). The relationship between capital structure and profitability. International Journal of Business and Social Science, 3(16), 104-112. 